\title{
GENETIC BASIS OF AMPHOTERIC REPRODUCTION IN ROTIFERS*
}

\author{
CHARLES E. KING广 and TERRY W. SNELL \\ Department of Biology, University of South Florida, Tampa, Florida 33620
}

Received 18.iii.77

\section{Summary}

\begin{abstract}
In the class Monogononta, female rotifers are identified by the type of egg they produce. Amictic females produce diploid eggs by mitosis. Mictic females meiotically produce haploid eggs which if unfertilised develop into haploid males, and if fertilised develop into diploid resting eggs. The present paper describes the occurrence and genetic basis of another type, the amphoteric female, in Asplanchna girodi. It is shown that amphoteric females produce both male and female offspring. Electrophoretic markers are used to demonstrate that female progeny of amphoterics have both maternal chromosomes. Thus simultaneous oogenesis by both meiosis and mitosis occurs in this type of rotifer.
\end{abstract}

IT is becoming increasingly apparent that the life cycle of monogonont rotifers is not as rigid as once believed. In addition to the two classical types of females-diploid, amictic females reproducing by ameiotic parthenogenesis, and diploid, mictic females producing haploid eggs by meiosis-a third type, the amphoteric female, has been described for four species (Sudzuki, 1955; Bogoslavsky, 1958, 1960; Ruttner-Kolisko, 1977; Snell and King, 1977). Females of this last type produce both female and male offspring. Although the genetic basis of both amictic and mictic reproduction is known (King, 1977; King and Snell, 1977) there have been no genetic studies of amphoteric reproduction.

Life table experiments, in which newborn amictic females are isolated in small watchglasses and examined at 12-hour intervals until they die, are particularly feasible for measuring birth and death rates in rotifers. In two of these experiments performed with Asplanchna girodi fed Paramecium tetraurelia we have found a total of seven amphoteric females. Three of the 630 isolated neonates $(0.48$ per cent) followed in the first experiment, and four of the 756 isolated neonates ( 0.53 per cent) in the second experiment produced both male and female offspring. Each of these seven amphoteric females belonged to a different clone. Thus, while amphoteric reproduction is not common, it must be regarded as a part of the reproductive repertoire of $A$. girodi.

Identification of amphoteric females requires isolated rearing and frequent removal of offspring. Thus it is seldom possible to recognise amphoterics until it is too late to perform a progeny test. However, one of the females in our study underwent a change in reproductive pattern relatively early (by age 4.5 days) and had a relatively long lifespan. This combination of unlikely events made it possible to perform the analysis reported in this paper. Data presented in fig. 1 are derived from this amphoteric female. During her 9-day lifespan, this female (designated I)

* This research was supported by grant No. BMS 73-00996 from the National Science Foundation.

$\dagger$ Present address: Department of Zoology, Oregon State University, Corvallis, Oregon 97331.

$39 / 3-D$ 
produced scven female and seven male offspring. Although technical considerations precluded testing as indicated later, the $F_{1}$ males appeared to be both morphologically and functionally normal and are, therefore, presumed to be haploid (Robotti, 1975; Jones and Gilbert, 1976). Two of the female offspring of I were isolated and their descendants examined. One of these $F_{1}$ females (II-1) was mictic, lived 4 days, and had two male progeny. The other $F_{1}$ female (II-2) was amictic, lived 10 days, and produced eight female offspring. The eight offspring of II-2 were in turn

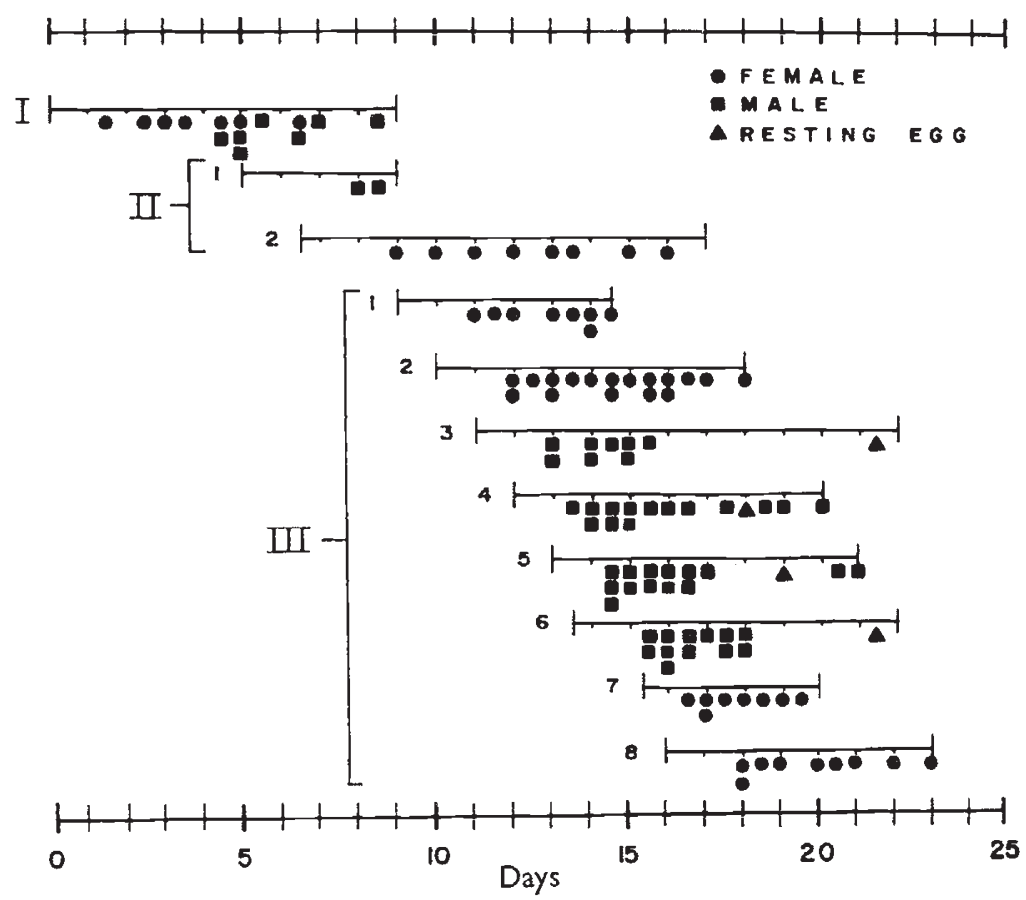

Fig. 1.-Reproductive history of an amphoteric female (I) belonging to Asplanchna girodi clone 5A1.

isolated and examined at 12-hour intervals for their cntire lives. Four of thesc (III-1, III-2, III-7, and III-8) were amictic females and four were mictic females that produced both males and resting (sexual) eggs.

There are three explanations that could account for amphoteric reproduction. The first hypothesis is that amphoteric femalcs produce only haploid cggs by meiosis. Sex of the offspring is determined by unknown factors, but both male and female offspring of an amphoteric parent are haploid. The second hypothesis also postulates that amphoteric females produce only haploid eggs by meiosis. Malc offspring are haploid, however, females are the result of a subsequent chromosome doubling (endomitosis) and are consequently diploid and completely homozygous. The third hypothesis is that amphoteric females produce two kinds of eggs: (1) haploid eggs by meiosis that, if unfertilised, develop into males, and (2) diploid eggs by mitosis which develop into females genetically identical to the parent. 
Hypotheses 1 and 2 predict that female offspring of an amphoteric parent possess only one allele per locus (hemizygous under hypothesis 1, homozygous under hypothesis 2). In contrast, hypothesis 3 predicts that female offspring of an amphoteric parent will be heterozygous at all heterozygous loci of the parent.

Clone $5 \mathrm{Al}$, from which the amphoteric female was derived by parthenogenesis, is known to be heterozygous at the malic enzyme locus (King, 1977). Thus, it is possible to examine the predictions of the proposed hypotheses by use of this electrophoretic marker. Although it is possible to obtain reliable isozyme bands with single females, males are haploid, greatly reduced in size, and neither feed nor grow after their birth. Minimum electrophoretic sample size for males is approximately 100 individuals, thus we have no information on male genotypes.

Electrophoretic analysis revealed that the amictic females in generation III were heterozygous, thus female II-2 must also have been a heterozygote. In turn we therefore know that II-2 was produced by a process of mitotic (rather than meiotic) oogenesis in the amphoteric female. This result clearly requires rejection of the first two explanations of amphoteric reproduction. We conclude that amphoteric females produce two types of eggs: (1) haploid eggs by meiosis which develop into males if unfertilised, or resting eggs if fertilised, and (2) diploid eggs by mitosis which develop into amictic females.

Two additional observations can be made from the data in fig. 1. As background, the stimulus that induces mixis in the closely related species $A$. sieboldi and $A$. brightwelli is known to be dietary tocopherol, vitamin $\mathrm{E}$ (Gilbert, 1968, 1977). The mixis stimulus in $A$. girodi is not known; however, it appears to be related to population density and not to tocopherol. The sequence of offspring production by amictic female II-2 was two amictic offspring, followed by four mictic offspring, followed by two amictic offspring. We presume that embryos do not normally respond to a mixis stimulus after visible differentiation has occurred (Gilbert, 1968). The sequence of offspring production then suggests that the mixis stimulus (or sensitivity to the stimulus) may change over a very short period of time (approximately 1 to 2 days).

The second observation concerns the susceptible period for fertilisation. $\mathrm{F}_{2}$ females III-3 through III-6 all produced males early in life. Since these females were isolated, their first exposure to males (i.e., their own male progeny) occurred when they were about 1.5 days old. Buchner, et al. (1967) found the susceptibility period for fertilisation was only a few hours after birth in $A$. sieboldi. It therefore appears that $A$. girodi females have much longer susceptibility periods and can be fertilised by their own male offspring.

In summary, amphoteric reproduction in $A$. girodi is based on meiotic oogenesis for the production of males, and mitotic oogenesis for the production of female offspring. Thus the amphoteric female appears to have the reproductive characteristics of both mictic and amictic females.

\section{REFERENCES}

Bogoslavsky, A.s. 1958. New data on the reproduction of heterogonous rotifers. Observations on the reproduction of Sinantherina socialis (Lin). Zool. Zh., 37, 1616-1623 (in Russian). 
Bogoslavsky, A. s. 1960. Observations on the reproduction of Conochiloides coenobasis Skorikov and the statement of a physiological category of females new to heterogonous Rotifera. Zool. Zh., 39, 670-677 (in Russian).

BUChaner, H., MUtschler, C., AND kiechile, H. 1967. Die Determination der Mannchen. and Dauerei-Produktion bei Asplanchna sieboldi. Biol. Zentralbl. 86, 5-9-621.

GILBERT, J. J. 1968. Dietary control of sexuality in the rotifer Asplanchna brightwelli Gosse. Physiol. Zool., 41, 14-43.

GILBERT, J. J. 1977. Mictic female production in monogonont rotifers. In Proceedings $I$ International Rotifer Symposium, ed. C. E. King. Schweizerbart-Verlag, Stuttgart. In press.

JONES, P. A., AND GILBERT, J. J. 1976. Male haploidy in rotifers: relative DNA content of nuclei from male and female Asplanchna. 7. Exp. Zool., 198, 281-285.

KING, C. E. 1977. Genetics of reproduction, variation, and adaptation in rotifers. In Proceedings I International Rotifer Symposium, ed. C. E. King. Schweizerbart-Verlag; Stuttgart. In press.

KING, C. E., AND SNELl, T. W. 1977. Sexual recombination in rotifers. Heredity (this issue). ROBOTTI, C. 1975. Chromosome complement and male haploidy of Asplanchna priodonta Gosse 1850 (Rotatoria). Experentia, 31, 1270-1272.

RUTTNER-Kolisko, A. 1977. Amphoteric reproduction in a population of Asplanchna priodonta. In Proceedings I International Rotifer Symposium, ed. C. E. King. SchweizerbartVerlag, Stuttgart. In press.

SNELL, T. W., AND KING, C. E. 1977. Amphoteric reproduction in Asplanchna girodi. In Proceedings I International Rotifer Symposium, ed. C. E. King. Schweizerbart-Verlag, Stuttgart. In press.

suDzukI, M. 1955. On the general structure and the seasonal occurrence of the males in some Japanese rotifers. III. Zool. Mag., 64, 189-193. 